\title{
Design Features when Using an Effective Microturbine as a Range Extending Engine
}

\author{
G. Nadareishvili' ${ }^{1)}$, A. Kostyukov' ${ }^{1)}$ K. Karpukhin ${ }^{1)}$ \\ ${ }^{1)}$ NAMI Russian State Scientific Research Center (Moscow, Russian Federation) \\ (C) Белорусский национальный технический университет, 2019 \\ Belarusian National Technical University, 2019
}

\begin{abstract}
The rapid development of electric vehicles stimulates the development of structures related to their operation. Including the use of the range extending engine for electric vehicles. The use of gas turbine engines for vehicles has always been of interest. The microturbine in the range extending engine is relevant today. However, the possibility of using a microturbine as part of a range extending engine is possible under several conditions. Microturbine should be successfully mated with a high-speed generator, and the whole structure should have a high efficiency and be economically advantageous. To create such a design, it is necessary to develop a simple microturbine with a design, equipped with a highly efficient heat exchanger, which allows to obtain high fuel and operational efficiency. Microturbine should have low temperatures on the turbine wheel to maintain high environmental parameters. The use of composite materials is necessary. The results of the development and technical characteristics of a single shaft microturbine of this class for use with a high-boring generator are presented, and its applicability as a range extending engine is justified. The main problems solved in the design of microturbines are shown: issues of thermal conditions, optimization of blade machines, flow in gas-air pipes. Power plants, based on the microturbine and high-speed generator, can be widely adopted on the basis of their simple and high operating characteristics, including the range extending engine as a range extending engine.
\end{abstract}

Keywords: microturbine, range extending engine, high-speed generator, energy efficiency

For citation: Nadareishvili G., Kostyukov A., Karpukhin K. (2019) Design Features when Using an Effective Microturbine as a Range Extending Engine. Science and Technique, 18 (6), 447-460. https://doi.org/10.21122/2227-1031-2019-18-6-447-460

\section{Особенности конструкции при использовании эффективной микротурбины в качестве двигателя с расширенным диапазоном}

\author{
Г. Надареишвили ${ }^{1)}$, А. Костюков ${ }^{1)}$, К. Карпухин ${ }^{1)}$ \\ ${ }^{1)}$ Государственный научный центр Российской Федерации ФГУП «НАМИ» (Москва, \\ Российская Федерация)
}

Реферат. Бурное развитие электромобилей стимулирует развитие конструкций, применяемых при их эксплуатации. Это подразумевает и растущий ассортимент двигателей для электромобилей. Использование газотурбинных двигателей для транспортных средств всегда вызывало определенный интерес. Применение микротурбины в качестве

\begin{tabular}{ll}
\hline Адрес для переписки & Address for correspondence \\
Карпухин Кирилл & Karpukhin Kirill \\
Государственный научный центр Российской Федерации & NAMI Russian State Scientific \\
ФГУП «НАМИ» & Research Center \\
ул. Автомоторная, 2, & 2 Avtomotornaya str., \\
125438, г. Москва, Российская Федерация & 125438, Moscow, Russian Federation \\
Тел.: +7 495 456-57-00 & Tel.: +7 495 456-57-00 \\
К.Karpukhin@nami.ru & K.Karpukhin@nami.ru
\end{tabular}


двигателя с расширенным диапазоном сегодня весьма актуальная проблема. Однако такая возможность имеется при соблюдении ряда условий. Микротурбина должна быть сопряжена с высокоскоростным генератором, а вся конструкция должна быть эффективной и экономически выгодной. Чтобы создать такую конструкцию, нужно разработать микротурбину, оснащенную эффективным теплообменником, который позволяет получить высокую топливную и эксплуатационную эффективность. Микротурбина должна иметь низкие температуры на колесе, чтобы поддерживать необходимые параметры окружающей среды. При этом следует использовать композитные материалы. Представлены результаты разработки и технические характеристики одновальной микротурбины данного класса для применения с высокопроизводительным генератором. Обосновано ее использование в качестве двигателя с расширенным диапазоном. Отмечены основные проблемы, решаемые при проектировании микротурбины: тепловой режим, оптимизация лопастных машин, потоки в газовоздушных трубах. Электростанции с микротурбиной и высокоскоростным генератором могут найти широкое применение в качестве двигателя с расширенным диапазоном на основе их простых и высоких эксплуатационных характеристик.

Ключевые слова: микротурбина, двигатель с расширенным диапазоном, высокоскоростной генератор, энергоэффективность

Для цитирования: Надареишвили, Г. Особенности конструкции при использовании эффективной микротурбины в качестве двигателя с расширенным диапазоном / Г. Надареишвили, А. Костюков, К. Карпухин // Наука и техника. 2019. T. 18, № 6. C. 447-460. https://doi.org/10.21122/2227-1031-2019-18-6-447-460

\section{Introduction}

At this stage of development of vehicles with combined engines, one of the development directions is the possibility of introducing a low-power gas turbine engine, or microturbine, as a converter of thermal energy into mechanical energy. This solution has a large number of positive aspects, such as fuel consumption, small size, highenergy efficiency and a number of performance indicators. In this case, the vehicle is also equipped with a high-speed generator for converting the microturbine's mechanical energy into electrical energy. That ensures the microturbine operation in a given range on the characteristic of optimal fuel consumption.

The structure of such vehicle generally includes: generating unit based on high-speed power generator and microturbines, the storage system and electric power storage, microturbine's fuel system and a traction electric drive.

More than ten developments of motor vehicles using the microturbine as an additional source of energy for vehicles with traction electric drives are already known in the world, which was called MiTRE (Microturbine Range Extender) [1, 2]. As an example, among the vehicles there are Trolza (Ekobus) buses, Delta Hypercar supercar, trucks such as Isuzu NPR, Mack Truck and Kenworth.

P. L. Klimov and E. A. Razumets [3] give the definition of the term "microturbine". The appearance of microturbines in the energy sector of the economy is also described. An overview analysis of the benefits of using distributed microtube generation in distribution networks has been made. For information, the technological process of a single-axis microturbine is given. Thus, the term "microturbine" used in this report can be clearly defined. It is an autonomous low-capacity thermal power plant that has an electrical capacity of up to $1000 \mathrm{~kW}$. At the same time, the microturbine is part of an electric generator that produces an extremely low level of $\mathrm{NO}_{x}$ emissions of $-15 \mathrm{ppm}$, which allows them to be installed even in housing estate. The minimum electric power microturbines starts at $30 \mathrm{~kW}$. Microturbines easily combined to a cluster, that is, a common energy system to produce large amounts of electrical power. Also in the cogeneration mode, the microturbine is able to solve the problems of heat supply of various objects. Trigeneration, applied to a microturbine, makes it possible to convert excess heat energy into cold, produced by absorption refrigerator.

Practically any kind of liquid or gaseous fuel can serve as a fuel for microturbines:

- natural gas with any pressure;

- biogas;

- associated petroleum gas with high sulfur content;

- diesel fuel;

- liquefied gas - propane;

- other fuels.

The conclusions of the article means that the main advantages of the distributed generation system based on microturbines are the following advantages:

- low noise level;

- low vibrations;

- small overall dimensions;

- a small number of moving parts;

- long maintenance intervals; 
- ability to work on various fuels (natural gas, gasoline, kerosene, naphtha, alcohol, hydrogen, propane, methane and diesel fuel).

However, it is worth noting that most microturbines used on an industrial scale use natural gas as a priority fuel.

As part of the work, a microturbine heat exchanger is being developed, so it was important to investigate work on improving the characteristics of this microturbine part. One of the aggressive phenomena in the operation of the microturbine is the thermal load on the heat exchanger. In the work [4] on reducing the thermal intensity of a vehicle microturbine heat exchanger, the authors A. A. Andreenkov and A. A. Dementiev consider a power plant based on a microturbine as part of a vehicle.

The authors have considered the advantages of motor vehicles with combined power plants, which include an electric generator based on a gas microturbine. The article widely identifies microturbine issues and solutions that positively affect performance. It was highlighted that priorities were identified and formulated in the automotive turbine industry and the ways of their solution were outlined, which, with a favorable policy, would allow transport microturbines to compete with piston engines, microturbines are especially attractive for use on heavy vehicles. The effective efficiency of the microturbine is a function of the ratio of air pressure behind the compressor and the temperature of the working gases to the corresponding parameters at the engine inlet, the efficiency of the compressor and the turbine, and the thermal efficiency (degree of regeneration) of the heat exchanger.

It is noted that the development of microturbines designed for vehicles is impossible without their operation together with a reliable, highly efficient, lightweight and compact heat exchanger. Using the example of Capstone microturbines, which heat the air behind the compressor from 205 to $510{ }^{\circ} \mathrm{C}$, it is stated that the specific fuel consumption has been improved almost 2 times compared to the cycle without regeneration; the heat efficiency of the heat exchanger is 0.86 , which for heat exchangers with overall mass parameters satisfying the layout of the microturbine is a high value, but far from limiting, when considering work in the specified conditions of heat exchangers of other schemes. Therefore, obtaining higher per- formance is also the goal of this applied scientific research.

An overview of current trends in the development of high-speed turbogenerators with permanent magnets is given in the study by E. Kachalina and others [5]. The materials provide an overview of both microgenerators (with a capacity of $1 \mathrm{~kW}$ ) and generators with a capacity of 1 to $10 \mathrm{MW}$.

The analytical review of microgenerators for our work is the most relevant. It discusses publications about turbogenerators with a capacity of less than $1 \mathrm{MW}$. It is indicated that microturbine generators are called machines with a capacity from 25 to $250 \mathrm{~kW}$, while at the same time, intensive development and research of microturbine generators in the range from a few watts to kilowatts rotating at ultra-high speeds is underway. They are also called microturbine generators, possibly due to the fact that they are being developed directly for installation in a combined microturbine engine.

The design features are as follows: the rotor of the electric machine, the compressor and the turbine are located on the same shaft of the microturbine generator. When starting the turbine, the electric machine operates in the engine mode, then switching to generator mode. As a generator, as a rule, a permanent magnet synchronous motor is used. Microturbine generators with a synchronous motor with permanent magnets produces: Capstone Turbine Corp., Elliott Energy (Calnetix), Honeywell, Bowman Power Systems, Northern Research and Eng. Corp., Allison Engine Corp., Williams International (USA), Turbec (Sweden), Siemens (Germany), Toyota, Nissan, Hitachi, Kawasaki (Japan) and others. The attention of such a large number of different manufacturers demonstrates the obvious promise of developing high-speed low-power synchronous motors with permanent magnets.

As permanent magnets in synchronous motors with permanent magnets, as a rule, intermetallic compounds based on rare-earth metals $-\mathrm{NdFeB}$ and SmCo are used. Advantages of $\mathrm{NdFeB} \mathrm{-} \mathrm{hig-}$ her energy than $\mathrm{SmCo}$, low price; disadvantages low temperature demagnetization (Curie temperature), a tendency to corrosion.

The conclusions are as follows.

1. With powers not exceeding $200-250 \mathrm{~kW}$, high-speed turbo-generators should be carried out on the basis of synchronous electric machines with magnetoelectric excitation. 
2. The experience of using contactless highspeed supports shows that of the three known types: gas-dynamic, gas-static and electromagnetic, petal-type gas-dynamic mount, which are a type of gas-dynamic mounts, have found primary use.

3. The use of rare earth magnets $(\mathrm{NdFeB}$, $\mathrm{SmCo}$ ) provides acceptable magnetic properties of composite rotors with their low weight and dimensions, which is especially important for high-speed electric machines.

4. When designing permanent-magnet synchronous motors, considerable attention should be paid to the configuration of the rotor and the method of placing the magnets, taking into account the circumferential linear velocity. Preferred is the option with surface magnets and bandage.

5. To ensure maximum mechanical strength with acceptable eddy current losses, it is advisable to use bandages made of carbon-fiber composites to hold the magnets.

According to these conclusions, some nuances can be noted: the use of gas-dynamic petal mounts does not need an external source of compressed gas, which is necessary for conventional gas-static mounts, and, accordingly, does not need an electric power source that supplies electromagnetic supports.

The article by A. C. Maia Thales and others [6] presents the experience of developing an electromechanical design of a high-speed generator driven directly by a turbine, which is made on a turbocharger.

The paper [7] presents the results of the design of the output axial diffuser of a power turbine of an automobile gas turbine installation and presents the results of mathematical modeling of the gas flow. As a result, the diffuser geometry has been optimized in order to reduce losses in it, which improves the power efficiency of the power turbine stage, contributing to the achievement of high effective microturbine efficiency.

The author of the work identifies two aspects in the development of the output diffuser of an automobile microturbine.

1) The diffuser is characterized by hydraulic resistance, the value of which must be reduced so that the high energy dissipation does not level the positive effect of the recovery of static pressure. Increasing the pressure loss in the diffuser requires a higher total gas pressure at the inlet to the turbine stage, which reduces the efficiency of the traction turbine and ultimately reduces the effective efficiency of the microturbine.

2) Creating efficient diffuser nozzles implies the freedom to build axially and radially; in the case of an automobile microturbine, the possibilities are significantly limited by the layout conditions and installation factors.

It is concluded that the output diffuser of an automobile microturbine should combine compactness and high work efficiency [7].

\section{System description}

One of the main reasons hindering the development of the market of power plants with microturbines is their lower electrical efficiency as compared with piston engines. For example, the electrical efficiency (multiplication of the effective efficiency of the microturbine by the efficiency of the electric generator) of one of the best microturbine power plants Capstone is $29 \%$, whereas for a gas piston engine this parameter is in the range $34-35 \%$ (for a power of $50 \mathrm{~kW}$ ).

There are several ways to increase the efficiency of gas turbine engines. This increase in the efficiency of its main elements (compressor, turbine, heat exchanger), the implementation of the vaporgas cycle, increasing the maximum cycle temperature of the gas turbine engine and carotene cycle through the introduction of intermediate air cooling between the compression steps in the compressor and the additional combustion chamber between the expansion steps in the turbine.

Fig. 1 shows that increasing the maximum gas temperature from $960{ }^{\circ} \mathrm{C}$ for turbines made of metals to $1500{ }^{\circ} \mathrm{C}$ leads to an increase in the effective efficiency of the microturbine to $38.4 \%$ (at an acceptable value of the degree of pressure increase in the compressor $\pi_{k}=3.5$ for microturbines with a power of $50 \mathrm{~kW}$ ), which is $4-5 \%$ more than that of reciprocating internal combustion engines with a power of $50 \mathrm{~kW}$. Nevertheless, this way of increasing efficiency still continues to be only promising. To date, in none of the commercially available microturbines (including the Ingersoll Rand and microturbine with a ceramic turbine wheel [8]), the gas temperature is not increased relative to the level used in metal microturbines $\left((900-950){ }^{\circ} \mathrm{C}\right)$. 


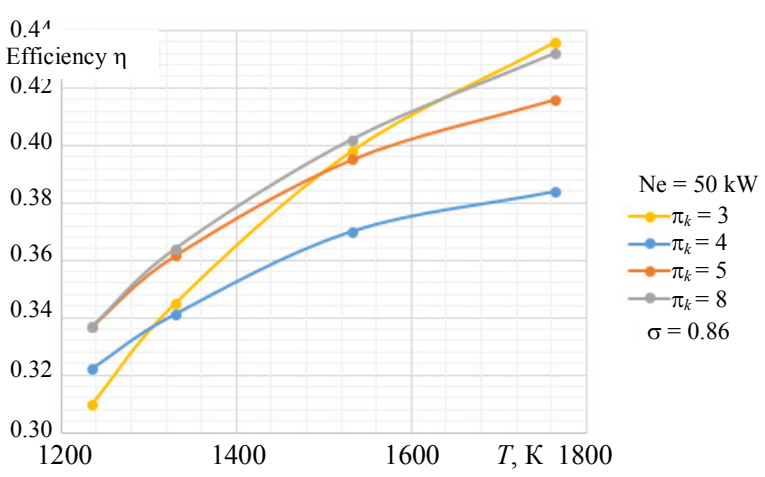

Fig. 1. Influence on the effective efficiency of the microturbine of increasing the temperature of the gas behind the microturbine combustion chamber with the degree of regeneration of the heat exchanger $86 \%$ $\left(\pi_{k}-\right.$ pressure ratio $)$

\section{Components. Bearing unit}

Analysis of the review of the scientific and technical literature showed that centrifugal compressors and radial-axial turbines are most often used in microturbines (Fig. 2). At low powers of gas turbine engines, they have unattainably high efficiency for axial blade machines at high revolutions. Well known for their high strength properties. The layout of the turbocharger in microturbines is implemented in the cantilever arrangement of the thrust bearing.

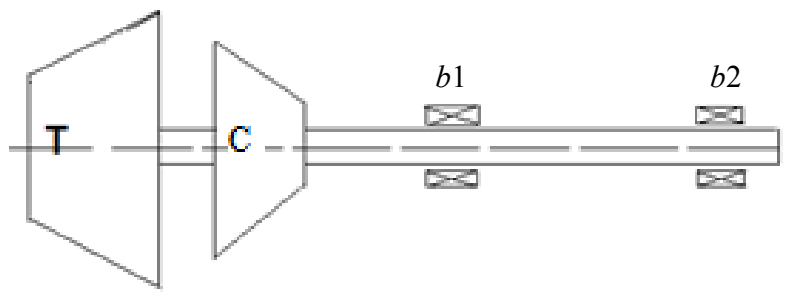

Fig. 2. Console arrangement of the turbine (T) and compressor $(\mathrm{C})$

\section{Components. Heat exchanger}

Rotary heat exchangers (regenerators) are superior to fixed heat exchangers (recuperators) in terms of efficiency and overall mass indicators (Fig. 3). The main problem of regenerators is their seals. Minimal leakages in seals have disc frame regenerators $(1.5-2.0 \%)$ [9].

To reduce the thermal deformations of the frame and, accordingly, to reduce leaks, as well as to allow the use of graphite seals (maximum temperature $\left.(450-470){ }^{\circ} \mathrm{C}\right)$, the frame is cooled.

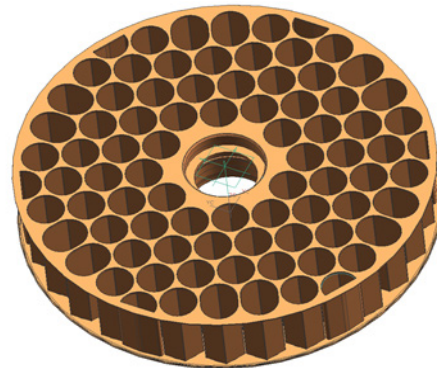

Fig. 3. Rotor frame heat exchanger

\section{Components. Combustion chamber}

The most promising for the microturbine, which is being developed, with a rotary heat exchanger will be a tubular low-toxic combustion chamber with enriched-lean combustion.

\section{Layouts}

The microturbine design (layout 1), made according to the scheme of cantilever placement of blade machines on the turbo-compressor shaft and with two rotating disk heat exchangers, is shown in Fig. 4.

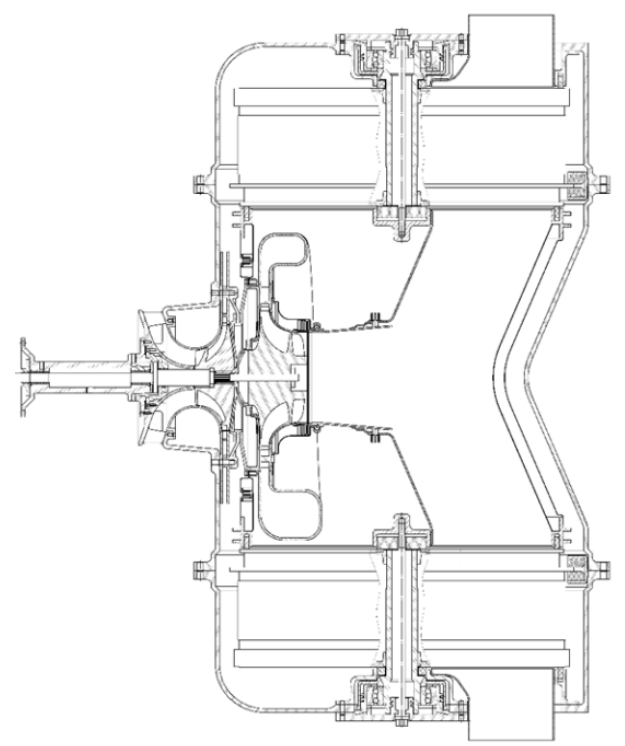

Fig. 4. Layout 1. Microturbine with two rotating heat exchangers, the axis of which is located normally to the axis of the turbocharger

The microturbine design (layout 2) is made according to the cantilever arrangement of blade machines on the turbo-compressor shaft and with one rotating disk heat exchanger, the axis of which is located normally to the axis of the turbocompressor shown in Fig. 5. 


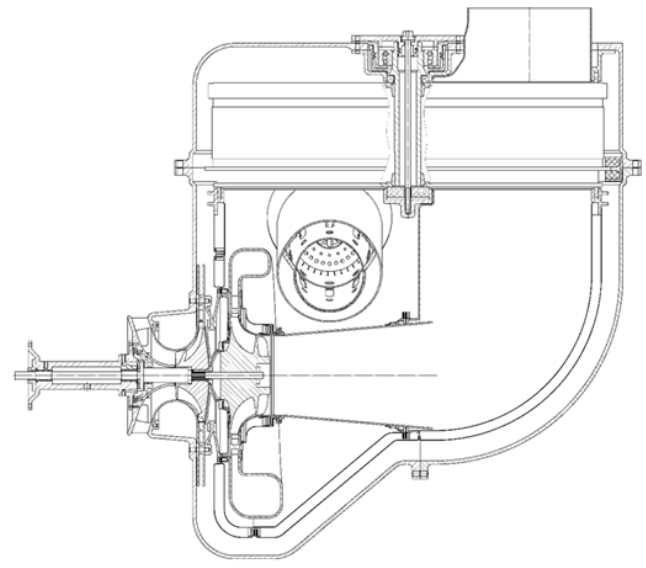

Fig. 5. Layout 2. Microturbine with one rotating heat exchanger, the axis of which is located normally to the axis of the turbocharger and with a conical diffuser behind the turbine

The microturbine design (layout 3), made according to the scheme of cantilever placement of blade machines on the turbo-compressor shaft and with one rotating disk heat exchanger, the axis of which is located parallel to the axis of the turbocompressor is shown in Fig. 6.

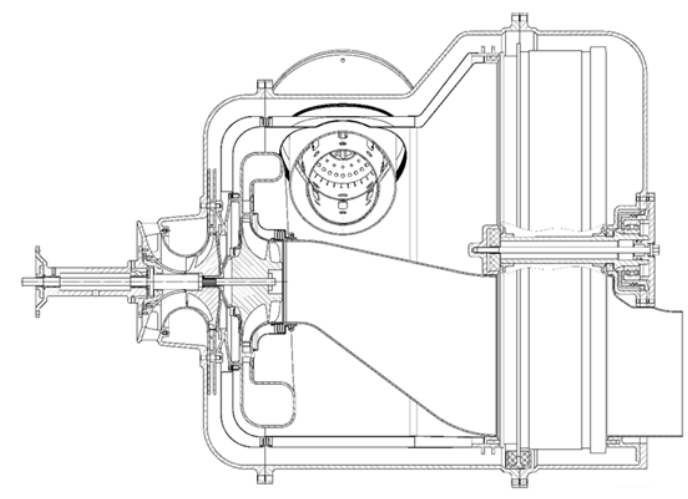

Fig. 6. Layout 3. Microturbine with one rotating heat exchanger, the axis of which is located parallel to the axis of the turbocharger and with a diffuser behind the turbine of complex shape

Fig. 7 shows the layout 4 . The layout has one rotating heat exchanger, the axis of rotation of which is parallel to the axis of the turbocharger. Compared to arrangement 3 , this arrangement has an elongated turbine diffuser and is made up of separate modules. The turbocharger module, the combustion chamber module and the heat exchanger module have their own bodies, which allows to reduce the dimensions of the chambers with high pressure and, accordingly, reduce the mass of their bodies and the mass of all micro- turbine, unload the diffuser behind the turbine and the turbine cover disk from the gas forces and thermal deformation forces, simplify assembly and disassembly and, accordingly, reduce the cost of overhaul. In addition, the calculated analysis of the efficiency of the diffuser behind the turbine of various lengths of the inlet gas manifold showed a significant advantage in terms of the efficiency of the microturbine with an elongated diffuser behind the turbine.

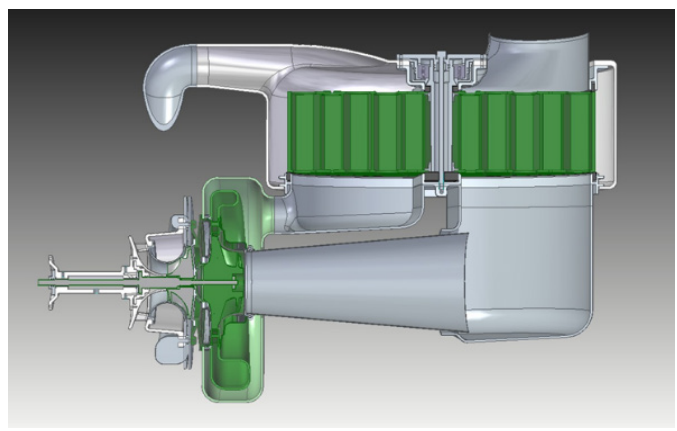

Fig. 7. Layout 4. Microturbine with one rotating heat exchanger, the axis of which is located parallel to the axis of the turbocharger and with an elongated turbine diffuser

\section{Calculations}

To confirm the parameters of the selected scheme (table 1), the calculation of the thermal state of the rotor of the designed microturbine was carried out. Such a calculation is decisive for the performance of the CCD and the efficiency value. The temperature state of the rotor was calculated as a result of solving the heat conduction problem in a stationary two-dimensional axisymmetric formulation. The solution of the problem can be divided into 3 main stages:

1) determination of boundary conditions;

2) simulation of the thermal state of the rotor;

3) analysis of the temperature field obtained.

Table 1

Presents the comparative indicators

of the design schemes of the microturbine

\begin{tabular}{|l|c|c|c|c|}
\hline \multicolumn{1}{|c|}{ Parameter } & Layout 1 & Layout 2 & Layout 3 & Layout 4 \\
\hline $\begin{array}{l}\text { Heat exchanger seal } \\
\text { length }\end{array}$ & - & + & + & + \\
\hline $\begin{array}{l}\text { Symmetrical body } \\
\text { elements }\end{array}$ & +- & - & - & - \\
\hline Simplicity of design & - & +- & +- & + \\
\hline $\begin{array}{l}\text { Efficiency of the dif- } \\
\text { fuser behind turbine }\end{array}$ & + & + & - & ++ \\
\hline Modularity design & +- & +- & +- & ++ \\
\hline
\end{tabular}


The results obtained were used to determine and localize the maximum rotor temperature. The temperature field was used as a PG for the subsequent calculations of the strength of parts and critical rotations of the microturbine.

\section{Boundary conditions \\ of thermal calculation}

The calculation was performed by simulating thermal conductivity in the rotor assembly in a non-conjugate formulation, i. e. without conducting a related flow simulation with heat exchange in the cavities and on the surfaces of the rotor. This approach was chosen because of the significantly lower resource intensity of the mathematical model and the absence of the need for its complexity, since for most cavities and rotor surfaces (including wheel surfaces), there are well-studied experimentally criterial dependences in the literature for calculating heat transfer coefficients. Also available were data on changes in temperature and heat transfer coefficients of the working medium in the flow parts of the wheels and in the secondary cavities, obtained from aerodynamic modeling using CFD. It also contributed to the formulation of sufficiently detailed PG on the surfaces of the flow parts of the wheels, the rear surfaces of the wheel disks and secondary cavities. It should also be noted that this approach made it possible to implement a model with low computational resourceintensiveness, which allows for rapid estimates of the rotor temperature, which is undoubtedly extremely important during the design iterative work on engine design.

Fig. 8 shows a sketch of the rotor assembly in section. The sketch shows the dependencies for which heat transfer coefficients were calculated on the external surfaces and surfaces of the internal cavities of the rotor. Heat transfer on the surfaces of the rotor was set with the help of 3 type boundary conditions, which represent the heat transfer coefficient and the reference temperature of the external environment. The heat transfer coefficients were set by empirical dependencies on the characteristic geometrical dimensions, speeds and properties of the working medium, type dependences $\alpha=f(L, W, \lambda, \ldots)$. For a number of rotor surfaces, heat transfer coefficients were calculated by empirical dependencies through similarity criteria such as the Nusselt number, Reynolds number, Prandtl number and characteristic geometric dimensions. These are dependencies like $\mathrm{Nu}=f(\mathrm{Re}$, $\operatorname{Pr}, L, \ldots)$ and $\alpha=(\mathrm{Nu} \cdot \lambda) / L$. Below boundary conditions are described in more detail.

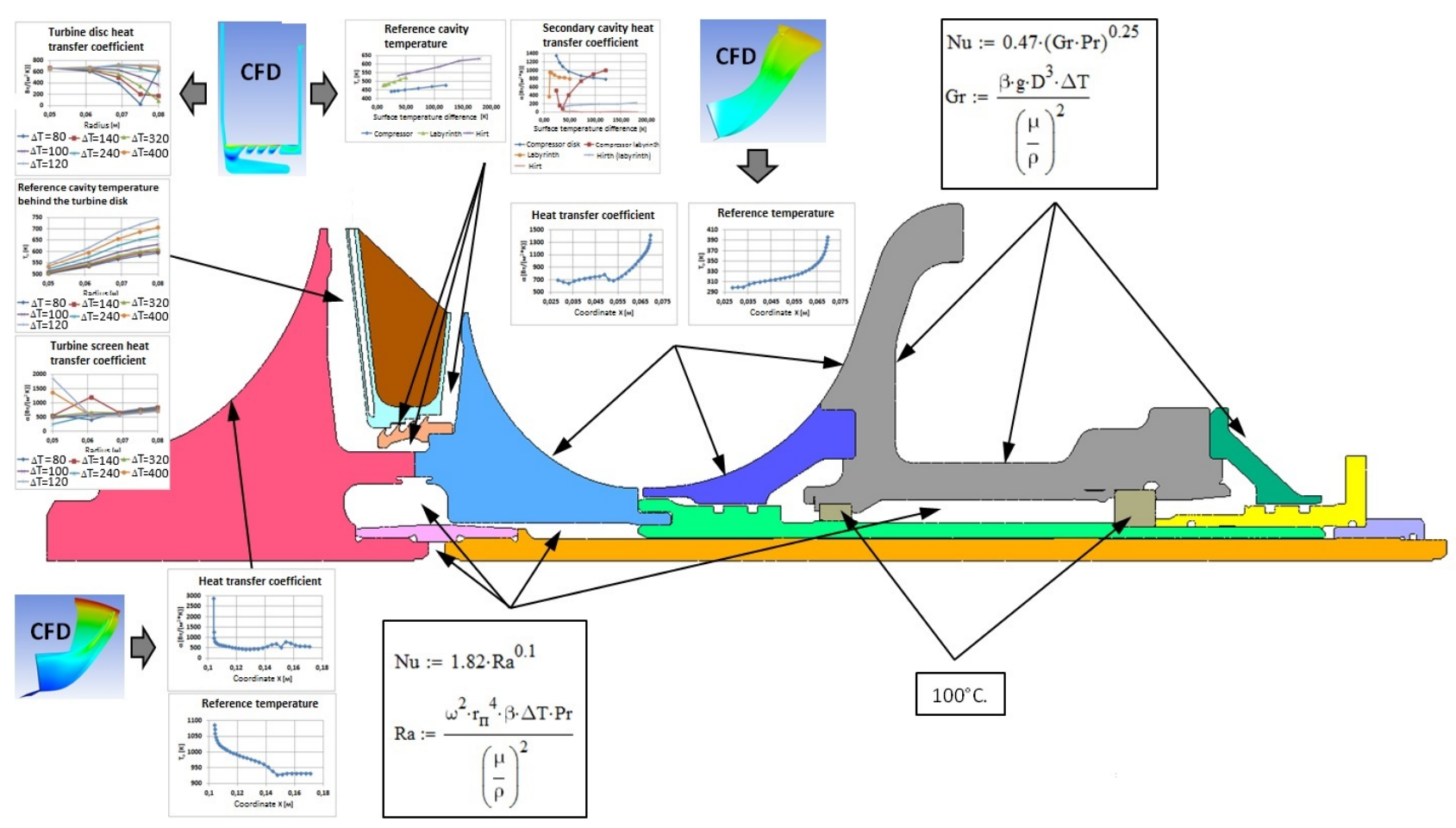

Fig. 8. Calculation scheme of the thermal state of the rotor assembly microturbine 


\section{Compressor}

The heat transfer coefficients and the reference temperature of the flow path of the compressor were also determined from aerodynamic (CFD) calculations (Fig. 9). The reference temperature in the flow part of the compressor is also practically independent of the temperature of the wheel and has a small gradient in the circumferential direction. Therefore, the results for the reference temperature and heat transfer coefficient were also averaged around the circumference, and in the thermal model of the rotor were set as a function of the length of the flow part.

Fig. 10 shows the profiles of the heat transfer coefficient and the reference temperature along the length of the flow path of the compressor, calculated from the aerodynamic calculation.

\section{Secondary cavities}

By secondary cavities we mean the cavity of the labyrinth seal and the cavity behind the disk of the turbine and compressor.

The flow in the secondary cavities is characterized by significantly lower costs compared to the main engine path and is mainly determined by the pressure drop between the leak gaps from the compressor and turbine sides and the labyrinth seal. Due to the relatively small consumption and sufficiently developed areas of the surfaces of

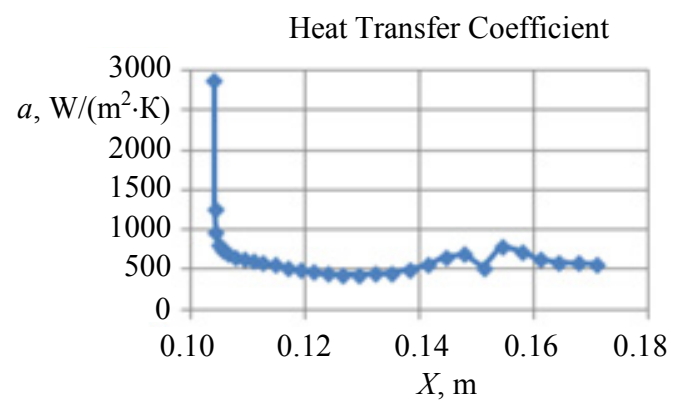

these cavities, the temperature of the air flowing through them varies considerably as it moves, namely, it increases as it flows from the compressor disk to the turbine disk due to intensive heat exchange with hot parts. Such a character of the flow requires the determination of PG in some cavities varying along the channel length and depending on temperature. Simulation of flow in the secondary path showed that such a channel is the cavity behind the turbine disk.

To determine the GI from heat transfer, in the secondary cavities, flow simulation was also used using a numerical model used to calculate leakage through labyrinth seals. This approach is more preferable for these cavities in comparison with the use of empirical dependencies, since allows much more accurately take into account the complex nature of the flow described above.

Thus, by calculating the flow, it was determined that in the cavities behind the compressor disk, in the labyrinth seal, and in the cavity between the labyrinth and the end spline connection (Hirt connection), the reference temperature and heat transfer coefficient vary slightly along the channel length and depend mainly on the temperature difference between the channel walls. In the cavity behind the turbine disk, as noted earlier, the reference temperature and heat transfer coefficient depend both on the channel length (disk radius) and on the temperature difference between the walls.

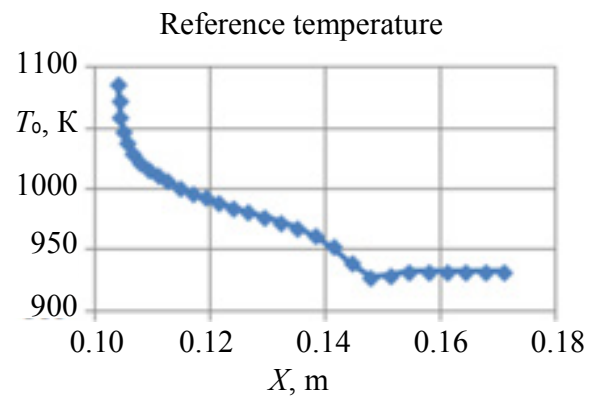

Fig. 9. The distribution of heat transfer coefficient and the reference temperature in the flow part of the turbine
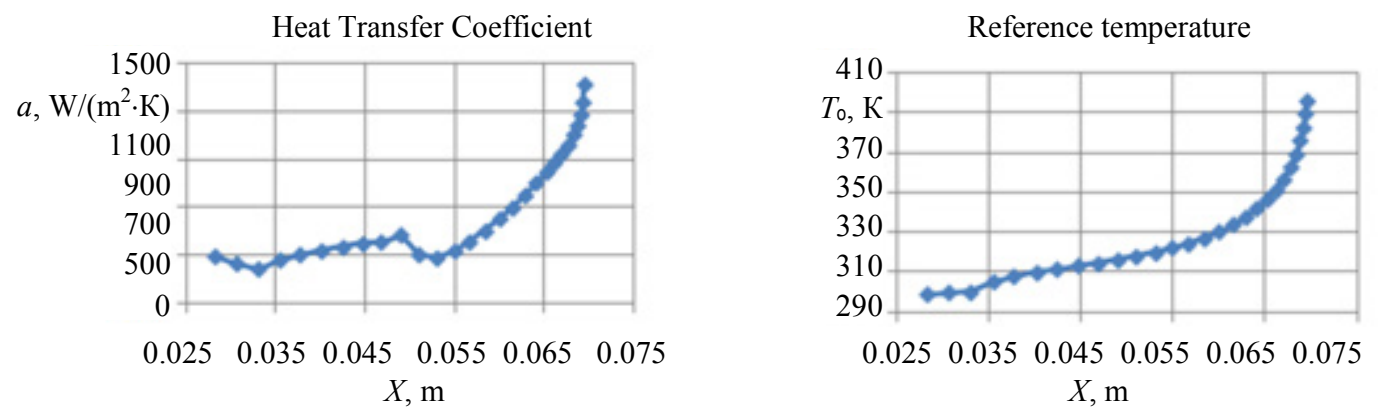

Fig. 10. The distribution of heat transfer coefficient and the reference temperature in the flow part of the compressor 
Fig. 11 shows the calculated heat transfer coefficients and the reference temperatures of the cavity behind the compressor disk, the labyrinth seal cavity, the cavity between the labyrinth and the front splines (Hirt connection) depending on the temperature difference between the surfaces.

Fig. 12 illustrates the calculated heat transfer coefficients for the back surface of the disk and the turbine screen, as well as the reference temperature of the cavity behind the turbine disk, depending on the radius and on the temperature difference between the walls.

\section{Internal weakly ventilated rotor cavities}

The internal cavities of the rotor include the following cavities:

- the cavity under the end spline connection (Hirt compound) $\alpha$;

- the cavity between the turbine disk, coupling pin and the turbine nut;

- the cavity between the supports, the shaft and the bearing housing.

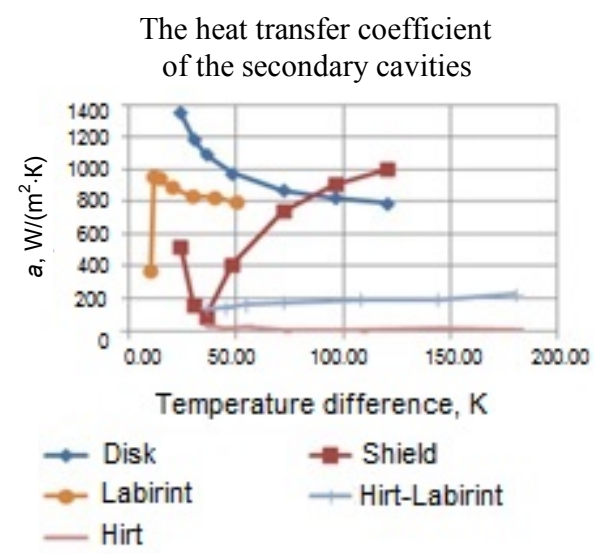

Heat transfer in such cavities has been studied quite well and is described by the empirical dependence of the form [6-10]

$$
\mathrm{Nu}:=1.82 \mathrm{Ra}^{0.1},
$$

where $\mathrm{Nu}$ - Nusselt number; $\mathrm{Ra}$ - Rayleigh number,

$$
\mathrm{Ra}:=\frac{\omega^{2} r_{p}^{4} \beta \Delta T \operatorname{Pr}}{\left(\frac{\mu}{\rho}\right)^{2}}
$$

$\omega$ - angular frequency; $r_{p}$ - radius at the periphery; $\beta$ - coefficient of thermal expansion; $\Delta T$ - temperature difference between the walls; $\mathrm{Pr}$ - Prandtl number; $\mu$-dynamic viscosity; $\rho$-density.

The reference temperature in the cavities was calculated iteratively in the process of calculating the thermal model of the rotor, as the average temperature of the cavity walls. The thermophysical properties of air were also calculated by the average temperature in the cavity [6-10].

\section{The reference temperature of the secondary cavities}

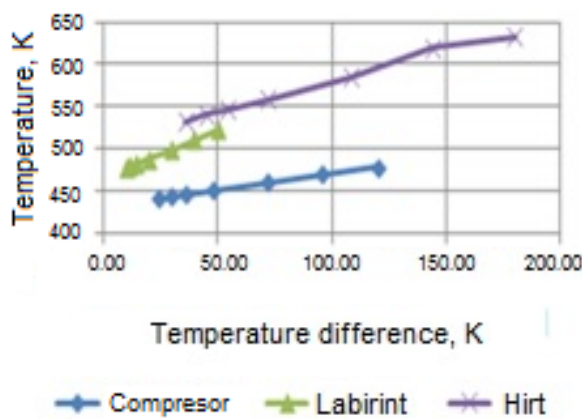

Fig. 11. Heat transfer coefficients and reference temperatures of secondary cavities depending on the temperature difference between the walls

Turbine disk heat transfer coefficient

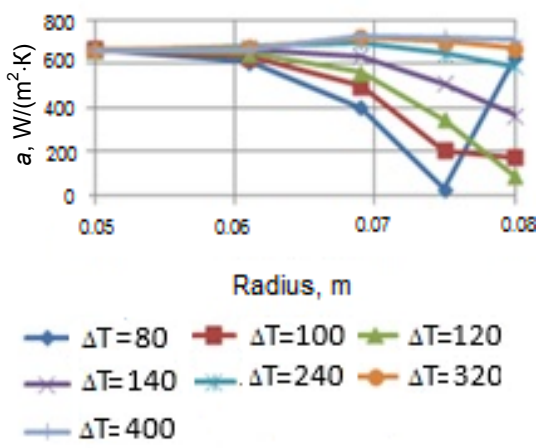

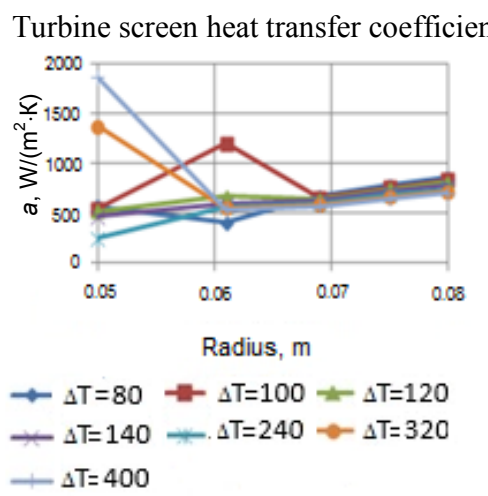

Fig. 12. Heat transfer coefficients and the reference temperature of the cavity behind the turbine disk, depending on the temperature difference between the walls 


\section{External surfaces of the bearing housing}

The heat exchange of the outer walls of the bearing housing with the external environment is carried out by natural convection caused by the temperature difference between the walls and the surrounding air. This type of heat transfer is well studied, and for cylindrical and inclined walls there are empirical dependencies of the form [7-11]

$$
\mathrm{Nu}:=0.47(\mathrm{Gr} \cdot \mathrm{Pr})^{0.25},
$$

where Gr - Grashof number,

$$
\mathrm{Gr}:=\frac{\beta g D^{3} \Delta T}{\left(\frac{\mu}{\rho}\right)^{2}}
$$

$D$ - diameter; $g$ - gravitational acceleration.

As the reference temperature, the ambient air temperature was set at $250{ }^{\circ} \mathrm{C}$.

\section{Rotor bearings}

On the rotor bearings, volumetric heat emission sources were specified in accordance with the calculations of heat generation in sliding bearings and experimental data from the SKF supplier for rolling bearings. In the slide support, heat dissipation from friction of $2 \mathrm{~kW}$ was set; in the rolling support, heat dissipation from friction of $700 \mathrm{~W}$ was set. Also in the supports were asked volumetric heat sinks that simulate oil cooling of bearings. The set power of the heat sinks was selected in such a way that the temperature of the supports did not exceed $1000{ }^{\circ} \mathrm{C}$, which is determined by the allowable working temperature range of the oil and the material of the supports.

It should be noted that in order to avoid overheating of the supports and keeping their temperature below $1000{ }^{\circ} \mathrm{C}$, practically all the heat $(\sim 98 \%)$ emitted by the bearings during operation should be removed due to oil cooling.

Thus, the boundary conditions for the thermal calculation of the rotor assembly were determined. The heat exchange similarity criteria described above and the temperature difference between the walls, depending on which they are calculated, were calculated iteratively in the process of solving the thermal model of the rotor.

\section{Thermal resistance of contacts}

Contact surfaces in various types of connections, such as connections with tension, bolted connections, etc., are not ideal due to the presence of asperities. As a result, at the contact point of such surfaces the temperature field has a characteristic jump, i. e. imperfect thermal contact takes place. Thus, for correct modeling of the temperature field of the rotor assembly, it is necessary to determine the thermal resistances of non-ideal contacts (Fig. 13).

The thermal resistance of the contact depends on the degree of roughness of the contacting surfaces, the materials from which they are made, and the contact pressure, i. e. force of compression of surfaces.

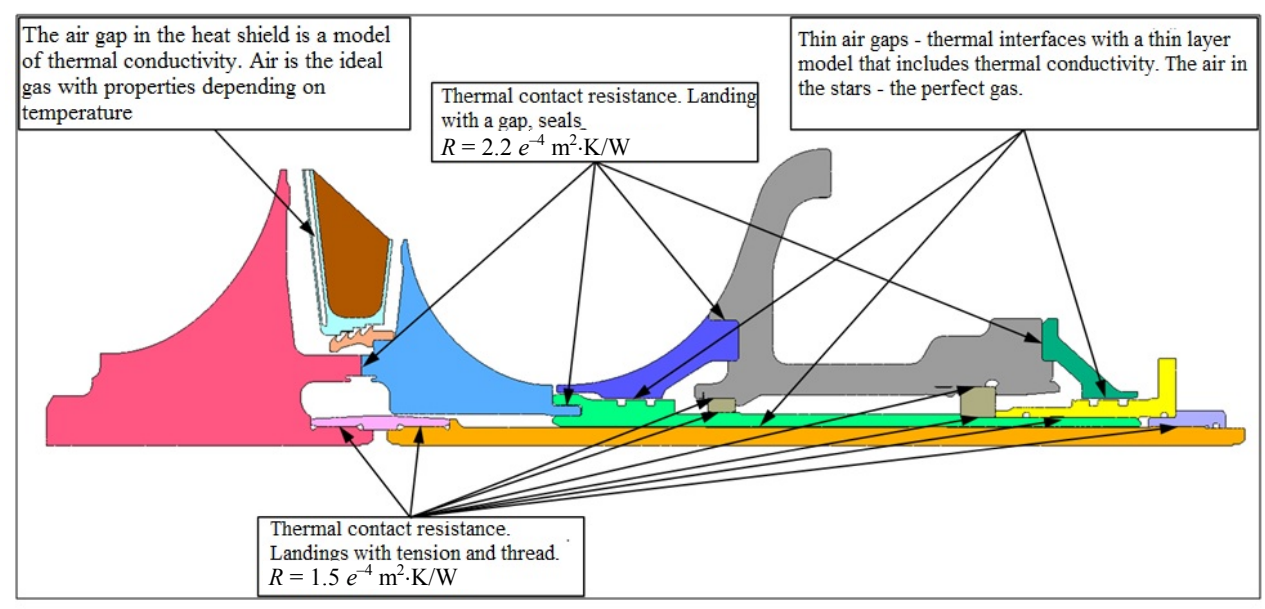

Fig. 13. Thermal resistances of rotor assembly contacts of microturbine 
The thermal resistance of the contact was calculated from empirical dependencies, and also compared with experimental data available in the literature [8-13]

$$
R_{k}:=\frac{1}{\left[\frac{2 \lambda\left(\frac{p_{k}}{3 \sigma_{b}}\right)^{n}}{\pi r_{m}}+\frac{\lambda_{c} K}{\delta_{e}}\right]},
$$

where $\lambda$ - reduced thermal conductivity coefficient,

$$
\lambda:=\frac{2 \lambda_{1} \lambda_{2}}{\lambda_{1}+\lambda_{2}}
$$

$p_{k}$ - contact pressure; $\sigma_{b}-$ ultimate strength of softer material at the temperature of the contact zone $T_{k} ; n$ - exponent; $\lambda_{c}$ - air thermal conductivity; $K$ - experimental coefficient; $r_{m}$ - radius of the contact patch; $\delta_{e}-$ equivalent thickness of the gap.

Some parts of the rotor are not in direct contact, but are separated by a thin air gap. Due to the small size of these gaps, the absence of the difference in the velocities of the walls and the high-pressure flow in them, the convective component of heat exchange can be neglected and only thermal conductivity can be taken into account. Especially for this kind of "contacts" there are models of interfaces with a thin layer, imitating a heat-conducting medium separating parts. This model was used to simulate thin air gaps. The air in the gaps was set as an ideal gas with temperature dependent properties.

The thermal resistances calculated by the given expression, as well as thermal models of the gaps are shown in Fig. 13.

\section{Simulation of the thermal state of the rotor}

Fig. 14 shows a view of the calculated region of the assembly and the grid of the thermal model of the rotor assembly. The heat conduction problem was simulated in a two-dimensional axisymmetric formulation. Convective sources and heat sinks are set by PG of the $3^{\text {rd }}$ kind (heat transfer coefficient and reference temperature), heat dissipation in the supports are set by means of volumetric energy sources, contact details are set using thermal interfaces (direct conjugation) taking into account the contact thermal resistance, and also taking into account the thermal resistance of thin air gaps, which are taken into account through thermal interfaces with a thin layer model.

The rotor assembly model consists of several design areas that describe the details of the rotor and are combined into an assembly through boundary conditions and thermal interfaces.

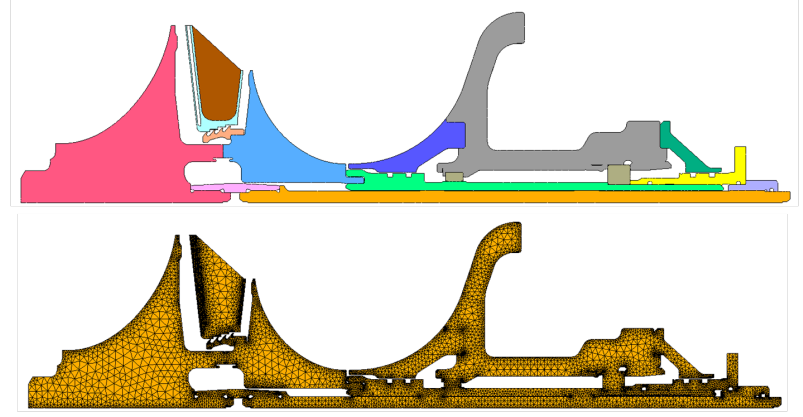

Fig. 14. View of the calculated grid of the rotor model

A computational grid with elements of the tetrahedral topology was used. The mesh size of the two-dimensional axisymmetric model was 20.000 elements.

\section{The results of the simulation \\ of the thermal state of the rotor. \\ Heat flow in the rotor}

Fig. 15 shows the scalar and vector fields of the density of heat flows in the rotor. The vector field shows in detail the local distribution of heat fluxes in the rotor and the direction of heat flow through the parts in the assembly.

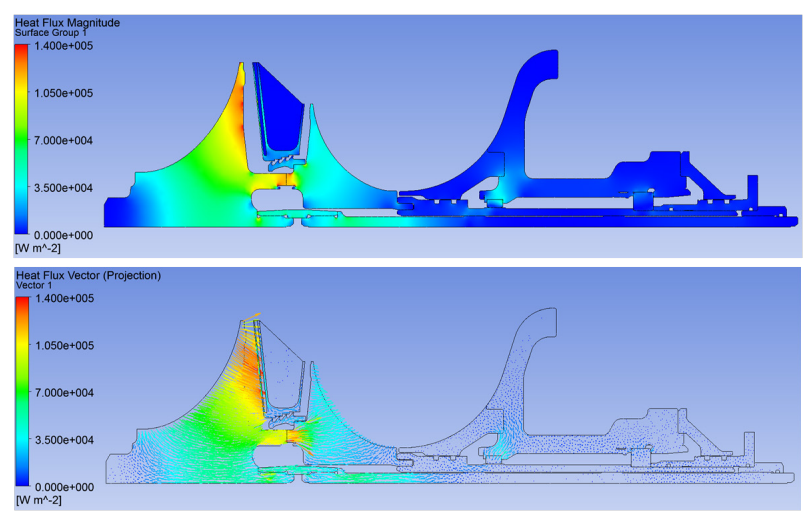

Fig. 15. Scalar and vector density fields of heat flows in the rotor

The results show that the main heat load falls on the turbine wheel from the hot gas in the flow part. The turbine wheel, being the hot part of the rotor, causes the main thermal load on the rotor coupling pin, which in turn, along with the compressor, transfers the heat flux to the rotor shaft. 
The main part of the heat from the turbine wheel is removed by intensive convection in the cavity behind the turbine disk. Cold air from a compressor degree leak passes through the labyrinth seal and enters the cavity behind the turbine disk. Passing through these secondary channels, air takes heat from hot parts, including from the turbine wheel, heating up along the direction of travel, and then through the leakage of the turbine stage enters its flow part, mixing with the gas of the turbine path. Also the heat flux field shows the proper the operation of the heat shield of the turbine, through which there is a fairly small heat flux. This prevents the compressor wheel from heating up, which in turn improves the strength characteristics and efficiency of the compressor stage. A significant part of the heat from the hot gas in the flow section of the turbine passes through the turbine disk into the end splines (Hirt connection) and through the thermal resistance of the contact due to heat conduction enters the compressor wheel. Also, part of the heat from the flow part passes through the wheel and the turbine nut into the rotor coupling pin due to thermal conductivity, also passing through the thermal resistance of the contact.

The heat flux entering the compressor wheel is removed from it by intensive convection in the flow part of the wheel due to significant consumption and the developed heat exchange surface. Also, a portion of the heat load of the rotor coupling pin is retracted through the air cavity to the compressor wheel due to convection and then also carried away by the main current in the flow part of the compressor. The rest of the heat is removed from the coupling studs into the rotor shaft through the resistance of the air gaps and further from the rotor shaft is dissipated from the developed surfaces of the casing of the input cavity of the compressor and the bearing casing, which are in an environment of cold outside air.

It is also clearly seen in the figure that, despite the sufficient oil cooling of the supports taken into account in the thermal model, a rather significant thermal load falls on the bearing housing and to some extent on the rotor shaft from the hydrodynamic support. This again indicates the need for effective cooling of the supports.

In general, the heat fluxes from the hot part of the rotor are sufficiently efficiently discharged and do not reach to a great extent the rotor shaft and its supports, which indicates a fairly successful rotor design in terms of thermal state. Significant heat flow comes to the compressor wheel and the rotor coupling pin in the hot part, however, how critical this circumstance can be given only by analyzing the temperature field of the rotor, carried out below.

\section{Temperature field}

Fig. 16 shows the calculated temperature field of the rotor assembly.

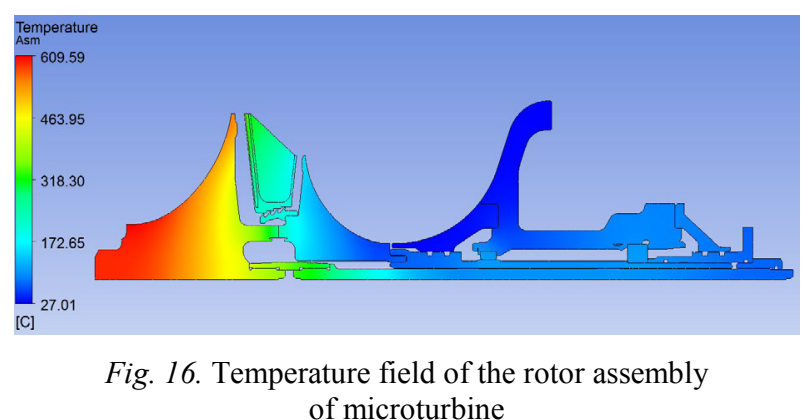

It can be seen that the maximum temperature is localized at the periphery of the turbine wheel, in the output part of the wheel, and also over the entire contact surface of the hot gas with the flow part of the turbine wheel. The rear part of the turbine disk turns out to be cooler due to the significant heat removal by cold compressor air of leakage into the cavities behind the turbine disk. It should be noted that this nature of heat transfer in the turbine wheel causes a significant temperature gradient over the wheel in the axial direction. However, the maximum temperature of the turbine wheel does not exceed $610^{\circ} \mathrm{C}$ (Fig. 17), which is a valid value for the heat-resistant alloy used.

Fig. 18 shows the temperature field of the compressor wheel. The figure clearly shows that, despite the significant heat flux coming from the turbine wheel through the Hirt connection, the temperature of the compressor wheel does not exceed $250^{\circ} \mathrm{C}$ and is localized in the zone of connection with the turbine wheel. The main part of the compressor wheel body does not exceed $200^{\circ} \mathrm{C}$. These temperatures are also acceptable for the titanium alloy used. It should be noted that a significant role in the heat flow insulation in the Hirt compound, the thermal resistance of the contact plays, which, in addition to the non-ideal contact of parts, is also due to the presence of an air gap between the teeth of the joint. The thermal resistances of the contacts, taken into account in the thermal model, are noticeable by gaps in the temperature field at the interface of the assembly parts. 


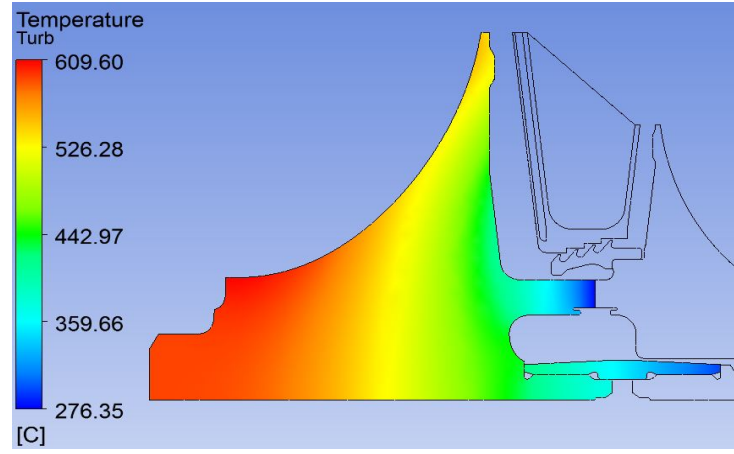

Fig. 17. Field temperature turbine wheels

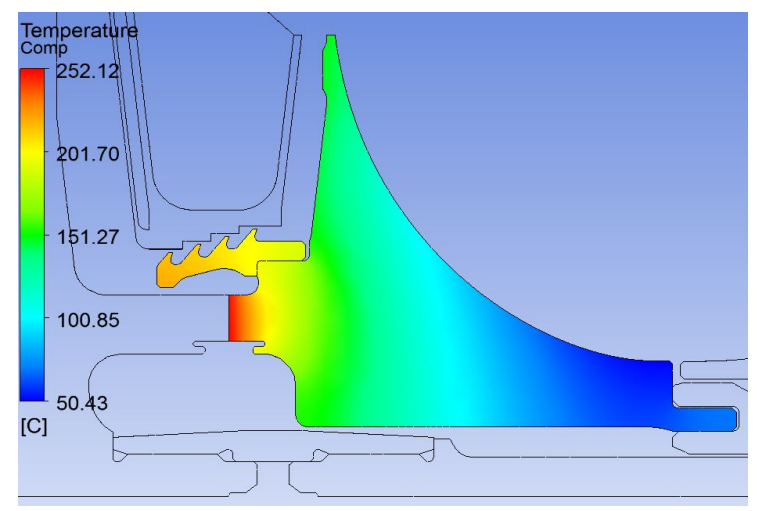

Fig. 18. Compressor wheel temperature field

Fig. 19 shows the temperature of the rotor pin. As described above, the heat flow is quite efficiently removed from the studs partially into the compressor through the air gap, partially into the rotor shaft and body parts.

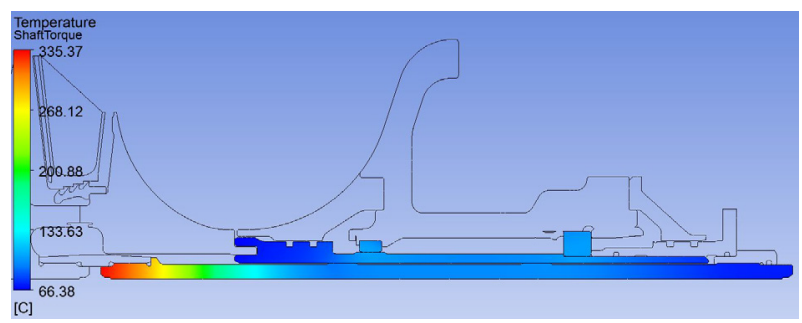

Fig. 19. Temperature field of the rotor coupling pin

In this regard, the heat coming from the turbine wheel through the turbine nut heats only a part of the stud located directly under the turbocharger. The rest of the studs remain cold, which increases the strength and resource characteristics of the rotor. The maximum temperature of the stud does not exceed $335{ }^{\circ} \mathrm{C}$, which is quite satisfactory for the alloy steel used.

Fig. 20 shows the temperature distribution over the shaft and rotor bearings. As can be seen from the figure, the temperature of the supports practi- cally does not exceed $100{ }^{\circ} \mathrm{C}$, due to the account in the model of oil cooling of the supports. Due to the fact that no significant heat comes into the rotor pin, and the incoming heat is quite efficiently removed, the rotor shaft practically does not perceive the heat load of the hot part. Therefore, the thermal state of the shaft is caused by heat flows coming from the supports, and the shaft remains sufficiently cold. The temperature of the supports, in turn, is due only to heat generation of friction and the efficiency of oil cooling. In other words, the supports also do not perceive the heat load of the hot part. It must be said that this is a rather important positive aspect of the developed structure, which undoubtedly contributes to improving the strength characteristics of the rotor and its resource.

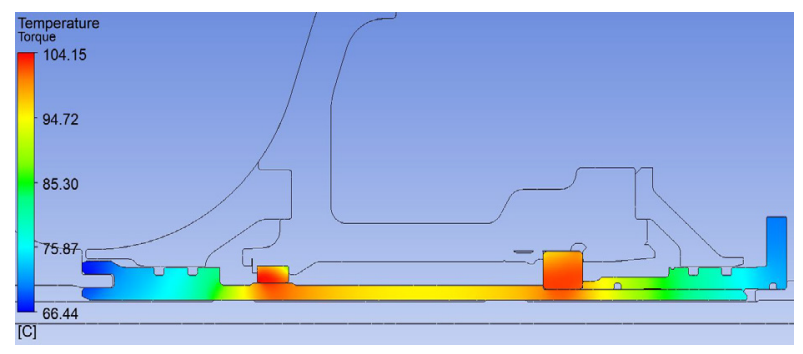

Fig. 20. Temperature field of the shaft and rotor bearings

The temperature of the bearing housing is shown in Fig. 21. As can be seen from the figure, the maximum body temperature is localized at the landing sites. The temperature of the body in these places does not exceed $100{ }^{\circ} \mathrm{C}$. The external temperature of the body does not exceed $80^{\circ} \mathrm{C}$ in the area above the rolling support and remains fairly low over the rest of the surface. It can be concluded that the bearing housing remains sufficiently cold, effectively dissipating the residual heat generated by the supports into the external environment.

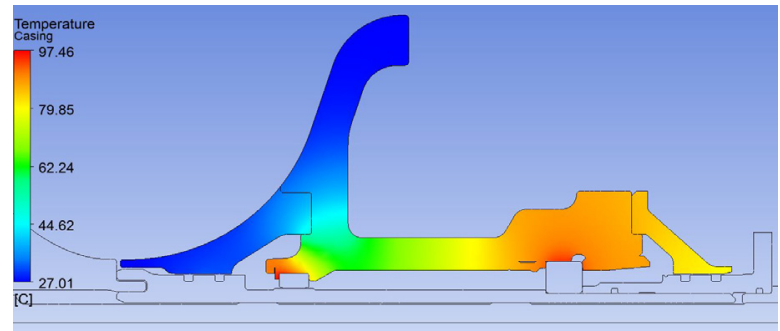

Fig. 21. Temperature field of the bearing housing

\section{CONCLUSIONS}

1. Based on the analysis performed, the fourth layout of the microturbine appears to be the most promising design. In general, the temperature field 
of the turbine qualitatively corresponds to the analysis of the integral heat fluxes described above.

2. A quantitative assessment of microturbine rotor temperatures shows that the maximum temperature of the turbine wheel is $610{ }^{\circ} \mathrm{C}$, the maximum temperature of the compressor wheel is $252{ }^{\circ} \mathrm{C}$, the maximum temperature of the coupling pin on the turbine side is $335{ }^{\circ} \mathrm{C}$, and the temperature of the rotor shaft and bearing assembly does not exceed $100{ }^{\circ} \mathrm{C}$.

3. Based on the calculated maximum temperatures of the turbine, compressor and shaft, it can be concluded that the temperature state of the main parts of the rotor is satisfactory, since at these temperatures, there is no significant reduction in the strength limits for the respective materials of the parts. So for the material of the VZhL-12 turbine, the strength and fluidity limits are significantly reduced at temperatures above $900{ }^{\circ} \mathrm{C}$; for the material of the VT6 compressor, a significant decrease in mechanical properties is observed at temperatures above $300{ }^{\circ} \mathrm{C}$ [14].

4. The resulting temperature field was used further as boundary conditions for calculating the strength and critical frequencies of the rotor. The use of a microturbine with an electric machine makes it possible to realize the advantages of a microturbine and the ability to use the installation as a Range Extender.

5. Optimum parameters and layout allow for high efficiency $38.4 \%$ and a miniature microturbine volume.

\section{ACKNOWLEDGEMENT}

This scientific article was prepared based on the results of applied scientific research, which was conducted with the financial support of the state in the name of the Ministry of Science and Higher Education of the Russian Federation, Agreement \#075-11-2018-233. The project reference number RFMEFI62518X0045.

\section{REFERENCES}

1. Kulikov I. A., Shorin A. A., Bakhmutov S. V., Terenchenko A. S., Karpukhin K. E. (2016) A Method of Powertrain's Components Sizing for a Range Extended Electric Vehicle. SAE Technical Papers 2016-01-8096. https://doi.org/10.4271/2016-01-8096.

2. Bakhmutov S. V., Karpukhin K. E., Terenchenko A. S., Kurmaev R. Kh., Kondrashov V. N., Sklyarinskiy S. F. (2015) Production of the Electric Vehicle Experimental Prototype with the Range Extender. Biosciences Biotech- nology Research Asia, (spl. Edn. 2), 533-538. https://doi.org/ $10.13005 / \mathrm{bbra} / 2230$.

3. Klimov P., Razumets E. (2018) Distributed Generation on the Basis of Microturbine. Definition of the Term, Description of the Technological Process. Sov-Remennye Nauchnye Issledovaniya: Aktual'nye Voprosy, Dostizheniya i Innovatsii, Sbornik Statei IV Mezhdunarodnoi Nauchno-Prakticheskoi Konferentsii [Modern Scientific Research: Current Issues, Achievements and Innovations, Collection of Articles of the IV International Scientific and Practical Conference.]. Penza, Nauka I Prosveshcheniye Publ., 54-56 (in Russian).

4. Andreyenkov A., Dementyev A. (2014) Decrease of Thermal Factor of Vehicle Micro Turbine Regenerator. Izvestiya Sochinskogo Gosudarstvennogo Universiteta $=$ Izvestiya Sochi State University, 32 (4-1), 24-29 (in Russian).

5. Kachalina E., Korobkov S., Kuzmichev V., Shirinskii S. (2017) Current Trends in the Development of High-Speed Permanent Magnet Turbogenerators. Izvestiya Kyrgyzskogo Gosudarstvennogo Tekhnicheskogo Universiteta I. Razzakova [Bulletin of the Kyrgyz State Technical University I. Razzakova], 44 (4), 162-168 (in Russian).

6. Thales A. C. Maia, Osvane A. Faria, Jose Eduardo Mautone Barros, Matheus P. Porto, Braz J. Cardoso Filh (2017) Test and Simulation of an Electric Generator Driven by a Micro-Turbine. Electric Power Systems Research, 147, 224-232. https://doi.org/10. 1016/j.epsr.2017.02.033.

7. Kosach L. A., Gornovsky A. S., Kostyukov A.V., Eliseev K. Yu. (2017) Optimization of Multi-Purpose Microturbine Turbine Diffuser. Izvestiya Moskovskogo Gosudarstvennogo Tekhnicheskogo Universiteta "MAMI", 3 (33), 21-27.

8. Philip J. Maziasz, Bruce A. Pint, Robert W. Swindeman, Karren L. More, Edgar Lara-Curzio (2003) Selection, Development and Testing of Stainless Steels and Alloys for High-Temperature Recuperator Applications. Proceedings of ASME Turbo Expo 2003 Power for Land, Sea. https://doi.org/10.1115/gt2003-38762.

9. Kostykov A. V. (2012) Microturbine with Efficiency of Over $43 \%$. Izvestiya Moskovskogo Gosudarstvennogo Tekhnicheskogo Universiteta "MAMI" = Izvestiya MGTU "MAMI”, 1 (2), 179-182 (in Russian).

10. Lokai V. I., Bodunov M. N. (1985) Heat Transfer in Cooled Parts of Gas Turbine Aircraft Engines. Moscow, Mashinostroenie Publ. 216 (in Russian).

11. Uong H. (1979) Basic Formulas and Heat Transfer Data for Engineers. Moscow, Atomizdat. 216 (in Russian).

12. Shlykov Yu. P., Ganin E. A., Tsarevsky S. N. (1977) Contact Thermal Resistance. Moscow, Energiya Publ. 328 (in Russian).

13. Salerno L. J., Kittel P. (1997) Thermal Contact Resistance. California, NASA Ames Research Center.

14. Tumanov A. T. (1975) The Mists Aviation Materials. Handbook in Nine Volumes. Moscow, ONTI Publ. (in Russian).

Received: 08.10.2019

Accepted: 29.11.2019

Published online: 06.12.2019 